into a series of primarily locally operated feeders to the main lines of its former rival. Only a short stretch between Hawleyville, Connecticut, and Hopewell Junction, New York, now plays an important part in the interchange of products between New England and the west and south, and no part is of real importance in the carriage of traffic between Boston and New York City.

This sketchy history of this road shows an attempt to build a trunk line railroad out of New England, the fruition of that hope, the almost frantic attempts to fatten up the ailing main line by means of branches to the main cities of southern New England and the final absorption of the system into the New Haven system, because of its dependence upon that system and upon the weak Erie Railroad for the traffic necessary to keep it going. It was perhaps unfortunate that, while this line was so unusual in New England history in the scope of the plan which brought it into existence, it should have been cursed with such poor management. It is hard to think of another instance in New England where a through line was built up of small lines all having been built with such a unity of purpose. In the Boston \& Albany as well as the Fitchburg Railroad system, the first links out of Boston were in each case conceived as local roads, and their managements long fought all attempts to make them parts of trunk lines between New England and the West.

Harvard University

George P. Baker, Jr.

\title{
In fllemoriam
}

The Society deeply regrets the loss by death of Walter Cabot Baylies on May 3, 1936. Long an outstanding man in the industrial, financial, and social life of New England, Mr. Baylies had been a member of the Business Historical Society since I 926.

Mr. Baylies was born in Taunton, Massachusetts, August I 3, I 862, and was graduated from Harvard in 1884 . He began his business career in the freight department of the Erie Railroad in New York, but in 1889 he moved to Boston. In 1896 he became a partner in Amory, Brown \& Company, agents for a number of cotton mills. His business interests soon widened: among the firms with which he had been actively connected were the New England Cotton Yarn Company, the Massachusetts Gas Companies, the 'Taunton \& New Bedford Copper Company, the B̈oston \& Lowell Railroad, the Boston \& Maine Railroad, the Suffolk Savings Bank, the New England Trust Company, the Boston Safe Deposit \& Trust Company, the Second 
National Bank of Boston, the Boston Manufacturing Company, the Indian Head Mills of Alabama, the International Paper \& Power Company, and the New England Power Company. Connected with the Edison Electric Illuminating Company of Boston from its beginning, he was its president from 1932 to 1935 when he resigned to become chairman of the board of directors.

Mr. Baylies was also a prominent philanthropist, giving support especially to the Children's Hospital, Perkins Institution for the Blind, the Infants' Hospital, and the Massachusetts Hospital School. His membership in many clubs and societies included the Colonial Society of Massachusetts and the Old Colony Historical Society.

The Society also suffered a real loss in the death of Albert Farwell Bemis on April 1 3, 1936. Born in Boston November I I, I 870, Mr. Bemis had, like Mr. Baylies, done much for the business and civic life of his native New England. He had been a member of the Business Historical Society since 1927 .

Mr. Bemis was a graduate of Massachusetts Institute of Technology of the class of 1893 . During the course of his career he had served as chairman of Bemis Brothers Bag Company, Building Products, Inc., and the Atlantic Gypsum Products Company; as president of the Housing Company and Bemis Industries, Incorporated; and as director of the Federal Reserve Bank of Boston, Boott Mills (Lowell, Massachusetts) and the Angus Company, Ltd. (Calcutta, India). He had also served as alderman for the City of Newton, member of the executive committee of the National Industrial Conference Board, trustee of Colorado College, and life member of the Corporation of Massachusetts Institute of Technology.

Mr. Bemis had been a member of the National Association of Cotton Manufacturers, Academy of Political Science, Royal Society of Arts, the American Oriental Society, and a number of other organization besides the Business Historical Society.

\section{Secretary's Column}

Since the publication of the last Bulletin the Society has received and gratefully acknowledges the following acquisitions:

From the American Telephone and Telegraph Company through its regional subsidiary telephone companies: 209 classified telephone directories for various cities in the United States. Chiefly for 1 920-36, but a few for 1897-1 920 .

From Mr. C. A. Chandler, Allston, Massachusetts: 14 advertising scrap books covering the period 1912-1929. 